\title{
Synthesis and Biological Activity of Eugenol-Copper Complex
}

\author{
SUPREET UPADHYAYA $^{1}$, JASHODA BEHARA ${ }^{2 *}$ and S.N.TEWARI ${ }^{1}$ \\ ${ }^{1}$ Crop Protection Division, Central Rice Research Institute, Cuttack-753006, Odisha, India \\ ${ }^{2}$ Department of Chemistry, Utkal University, Vani Vihar, Bhubaneswar-4, Odisha, India \\ supali29@gmail.com
}

Received 21 April 2013 / Accepted 4 October 2013

\begin{abstract}
Metal chelate of bioactive metal ion $\mathrm{Cu}(\mathrm{II})$ with eugenol was chelated for improving the ligand's efficiency and the complex synthesized was characterized through FT-IR, TG-DTA, AAS and elemental analysis. The composition of eugenol-copper in complex was found to be 1:1 through Job's method. In vitro antimicrobial test of eugenol, eugenol-copper complex and $\mathrm{CuSO}_{4} \cdot 5 \mathrm{H}_{2} \mathrm{O}$ was conducted against phytopathogenic fungi Pyricularia grisea Sacc., Helminthosporium oryzae Breda de Haan and Curvularia lunata (Wakker) Boedijin through conidial germination test that revealed enhanced fungi-toxicity of the complex compared to either eugenol or $\mathrm{CuSO}_{4} \cdot 5 \mathrm{H}_{2} \mathrm{O}$ alone especially against the former pathogen.
\end{abstract}

Keywords: Eugenol-copper complex, FT-IR, TG/DTA, Elemental analysis, Job’s method, Fungitoxic activity

\section{Introduction}

Eugenol is member of phenylpropanoid class of chemical compound and main constituent of essential oil obtained from Pimenta racemosa (bay leaves), Cinnamomum verum (cinnamon leaf), Syzygium aromaticum (clove) and Ocimum species ${ }^{1-3}$. The first biological activity of eugenol, antibacterial, activity was reported by H.A. Bartels ${ }^{4}$. It possesses antifungal, bactericidal, insecticidal, larvicidal, nematicidal ${ }^{5-8}$. It also shows antidepressant ${ }^{9}$, antioxidant, anti-inflammatory activities coupled with anti-animal toxin with analgesic properties for human antiseptic in traditional medical practices ${ }^{10-12}$. It finds wide application in perfumeries, flavourings and in medicines. Eugenol affects the peripheral aspects of cardiovascular system. The heart is not the principle site of action since eugenol has little effect on the electrical activity and only slightly reduces the contractile force unless a little fatal dose is used ${ }^{13}$. It is used in combination with zinc oxide as a surgical dressing, pulp capping cavity liner, temporary cement, in mouth washes and endodontic therapy, in study of mucous secretions and in gastric cytology ${ }^{14,15}$. It is important that in several studies, this natural compound was reported to be non- genotoxic and noncarcinogenic $^{3,12}$. In the present study we synthesized complex of eugenol with copper to enhance the antifungal activity of the former against phytopathogenic fungi viz., Pyricularia 
grisea Sacc., Helminthosporium oryzae Breda de Haan and Curvularia lunata (Wakker) Boedijin responsible to cause blast, brown spot and grain discoloration diseases in rice affecting yield.

\section{Experimental}

All the chemicals used were of A.R. grade and the solvents were of G.R. grade.

\section{Synthesis of complex}

Eugenol and $\mathrm{CuSO}_{4} \cdot 5 \mathrm{H}_{2} \mathrm{O}$ (in form of solution in methanol) in ratio 5:1 were mixed together and kept for 3-4 days at room temperature. The blue precipitate was obtained that was filtered and washed with diethyl ether and dried in desiccator. After recrystallization, the powder obtained was scrapped out from the beaker and kept in clean glass vials.

\section{Spectral and elemental analysis of the complex}

The complex was characterized by FT-IR by Perkin Elmer spectrum RX1, thermogravimetric analysis (TG), differential thermal analysis (DTA) were done through Perkin Elmer STA 6000 and $\mathrm{C} \mathrm{H} \mathrm{N}$ analysis by Elementar Vario EL III and $\mathrm{Cu}$ analysis through AAS by ECIL 4139 .

\section{Composition of the complex}

The composition of the complex was determined by Job's method using Cecil CE 7400 at $780 \mathrm{~nm}$. The concentration of eugenol and $\mathrm{CuSO}_{4} \cdot 5 \mathrm{H}_{2} \mathrm{O}$ was $3 \times 10^{-4} \mathrm{M}$.

\section{Antifungal activity of the complex}

Complex, eugenol and $\mathrm{CuSO}_{4} \cdot 5 \mathrm{H}_{2} \mathrm{O}$ were tested against fungal pathogens viz. P. grisea, H.oryzae and C.lunata under in vitro conditions through conidial germination test as per method given by Nene and Thapliyal ${ }^{16}$ at 100 ppm, 10 ppm, 1 ppm, $0.1 \mathrm{ppm}, 0.01 \mathrm{ppm}$. Conidial suspension of 7 day old pure culture of the test pathogens with 30-35 conidia per microscopic field $\left(1.26 \mathrm{~mm}^{2}\right)$ were placed separately on each glass slide having treatment and incubated in moist chamber at $24{ }^{\circ} \mathrm{C}$ for $24 \mathrm{~h}$. Observations on conidial germination (\%) and the patterns of fungitoxicity were recorded using phase contrast microscope, Olympus BX51 at 10X magnification after $24 \mathrm{~h}$ of incubation. Appropriate controls were maintained keeping three replications in each case and the experiment was repeated thrice. Data on germination was transformed to angular value and statistically analyzed. No conidial germination was accorded the numerical value $2 \%$ for the purpose of statistical analysis that was done using Cropstat 7.2 developed by International Rice Research Institute (IRRI).

\section{Results and Discussion}

\section{Spectral and elemental analysis}

FT-IR analysis that revealed that peak at $3514 \mathrm{~cm}^{-1}$ in eugenol disappeared due to coordination of $\mathrm{OH}$ group in metal in case of complex. Peak at $3367 \mathrm{~cm}^{-1}$ appeared due to coordinated water. Peak at $1619 \mathrm{~cm}^{-1}$ in $\mathrm{C}=\mathrm{C}$ in aromatic ring remains as such. $1092 \mathrm{~cm}^{-1}$, $1159 \mathrm{~cm}^{-1}$ and $1198 \mathrm{~cm}^{-1}$ is due to C-O-C stretching (symmetric and asymmetric). New band at $603 \mathrm{~cm}^{-1}, 585 \mathrm{~cm}^{-1}, 517 \mathrm{~cm}^{-1}$ is due to $\mathrm{Cu}-\mathrm{O}$ bonding (Figure 1) which is not found in FT-IR spectra of eugenol. These are characteristic peaks of metal-oxygen bonding. Hasanvand et al., ${ }^{17}$ and Volanti et al., ${ }^{18}$ reported peaks at $580 \mathrm{~cm}^{-1}, 610 \mathrm{~cm}^{-1}$ and $520 \mathrm{~cm}^{-1}$ for $\mathrm{Cu}-\mathrm{O}$ bonding. 


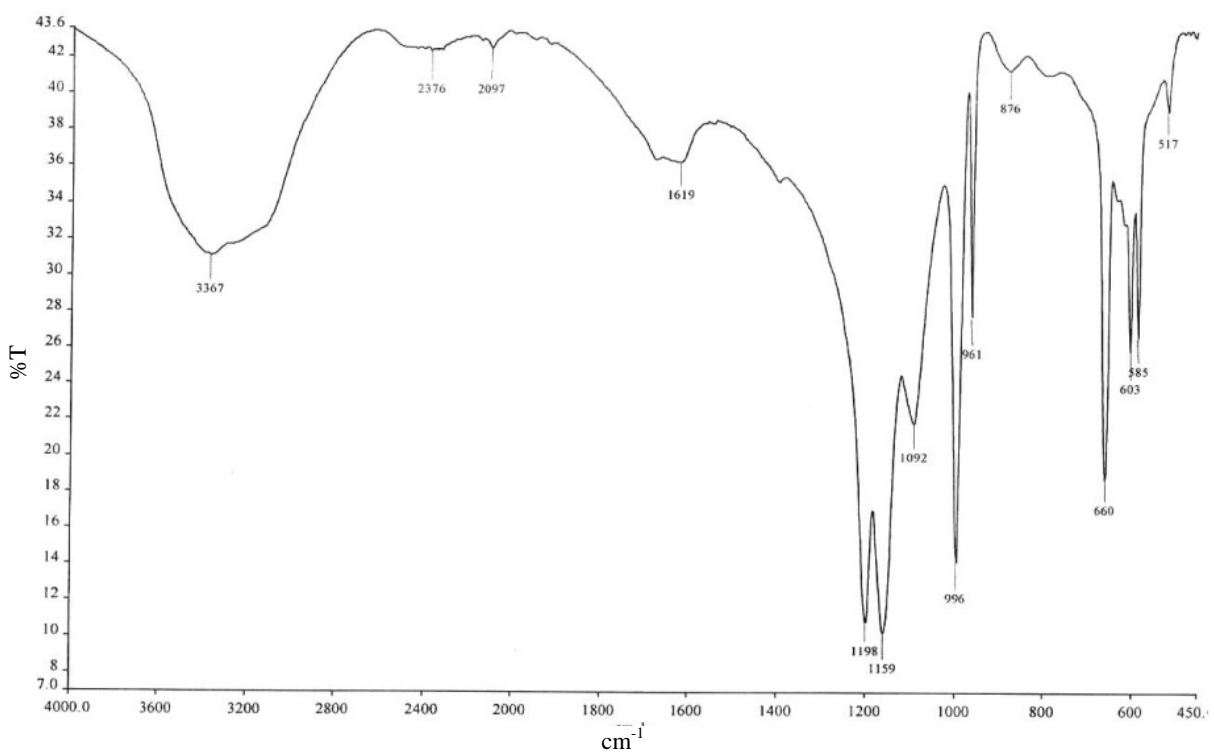

Figure 1. FT-IR spectrum of complex

Thermal analysis methods are widely used for thermodynamic investigation of the complex formed. TG curve of the complex is shown in Figure 2. According to TG data of complex from temperature $35.76{ }^{\circ} \mathrm{C}$ to $735.5^{\circ} \mathrm{C}$, decomposition of the complex showed following steps. The first weight loss from $40-47^{\circ} \mathrm{C}$ was about $3 \%$ corresponding to release of absorbed water molecule.

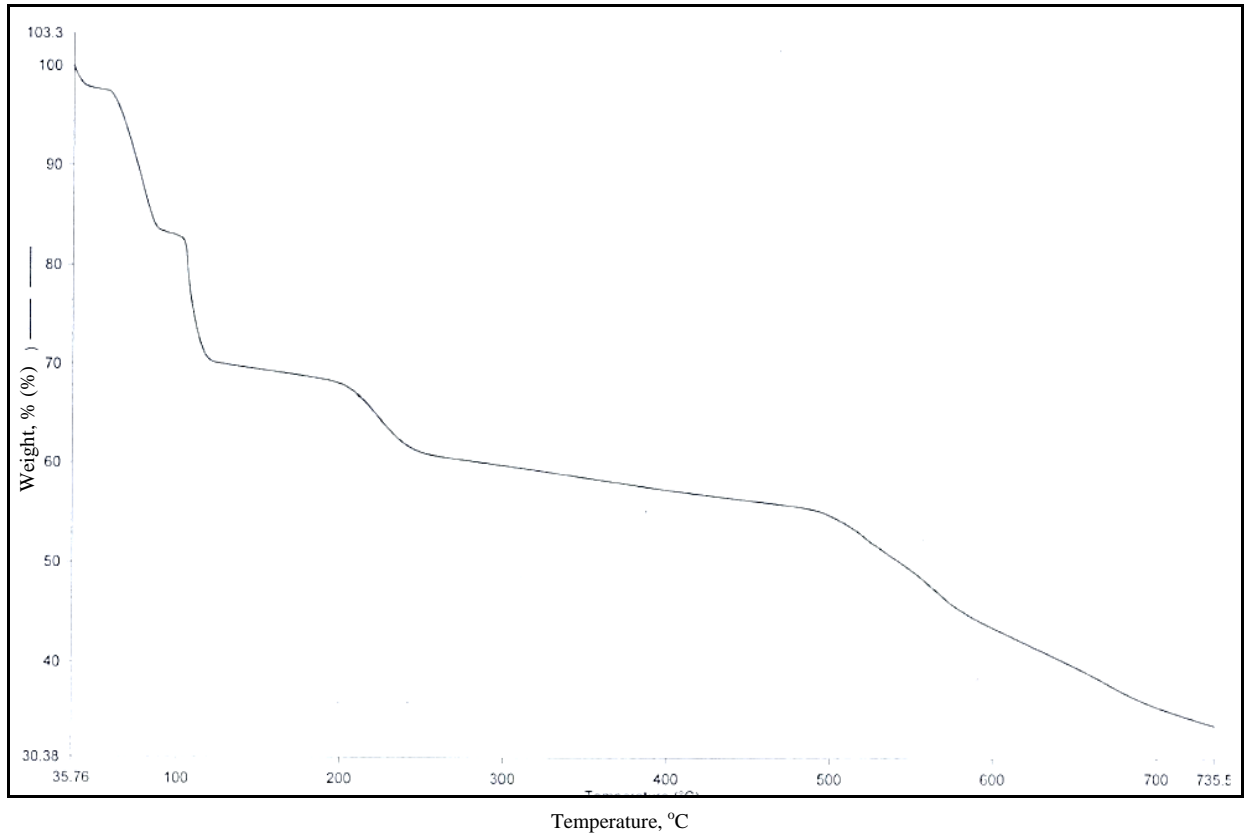

Figure 2.TG spectrum of complex 
The second weight loss from $50{ }^{\circ} \mathrm{C}-98{ }^{\circ} \mathrm{C}$ was $12 \%$ corresponding to the release of two coordinated water molecules, with the maximum rate of weight loss occurring at $75.16{ }^{\circ} \mathrm{C}$. Third weight loss of $12 \%$ from $100{ }^{\circ} \mathrm{C}$ to $110{ }^{\circ} \mathrm{C}$ indicated the release of two more coordinated water molecule from the complex. Maximum decomposition rate of water molecules was recorded at $109.19{ }^{\circ} \mathrm{C}$ (Figure 2 and 3). The next weight loss of $13 \%$ occurred from $110{ }^{\circ} \mathrm{C}$ to $225^{\circ} \mathrm{C}$ corresponds to release of allylic group from the complex. The maximum decomposition rate of allylic group was recorded at $222.63{ }^{\circ} \mathrm{C}$. The weight loss from $230{ }^{\circ} \mathrm{C}$ to $500{ }^{\circ} \mathrm{C}$ was $3 \%-4 \%$ corresponds to the decomposition of complex forming gases viz. $\mathrm{CO}, \mathrm{CO}_{2}$. Beyond $500{ }^{\circ} \mathrm{C}$, weight loss was about $26 \%$ and $7 \%$ corresponding to release of benzene ring and methoxy group. Also two peaks $521{ }^{\circ} \mathrm{C}$ and $563{ }^{\circ} \mathrm{C}$ in DTA suggests the decomposition of benzene and methoxy group. Above $700{ }^{\circ} \mathrm{C}$, a black residue remains corresponding to $\mathrm{CuO}$. The enthalpy data reveals that the peak at $225{ }^{\circ} \mathrm{C}$ shows exothermic reaction and that at $109{ }^{\circ} \mathrm{C}$ shows endothermic reaction (Figure 4).

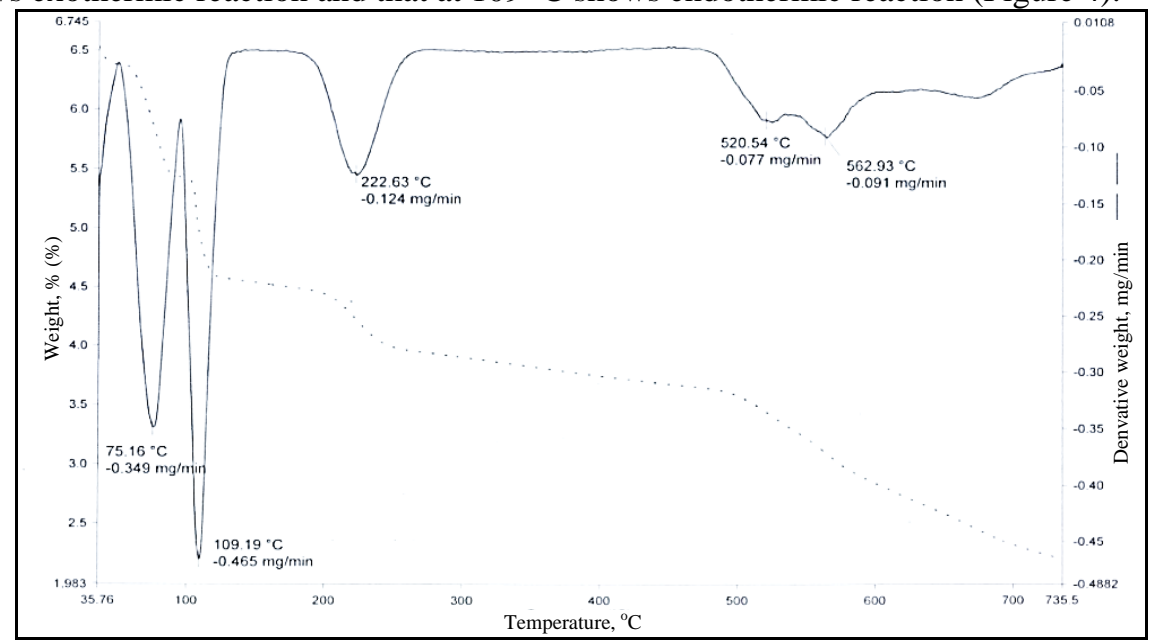

Figure 3. DTA of the complex

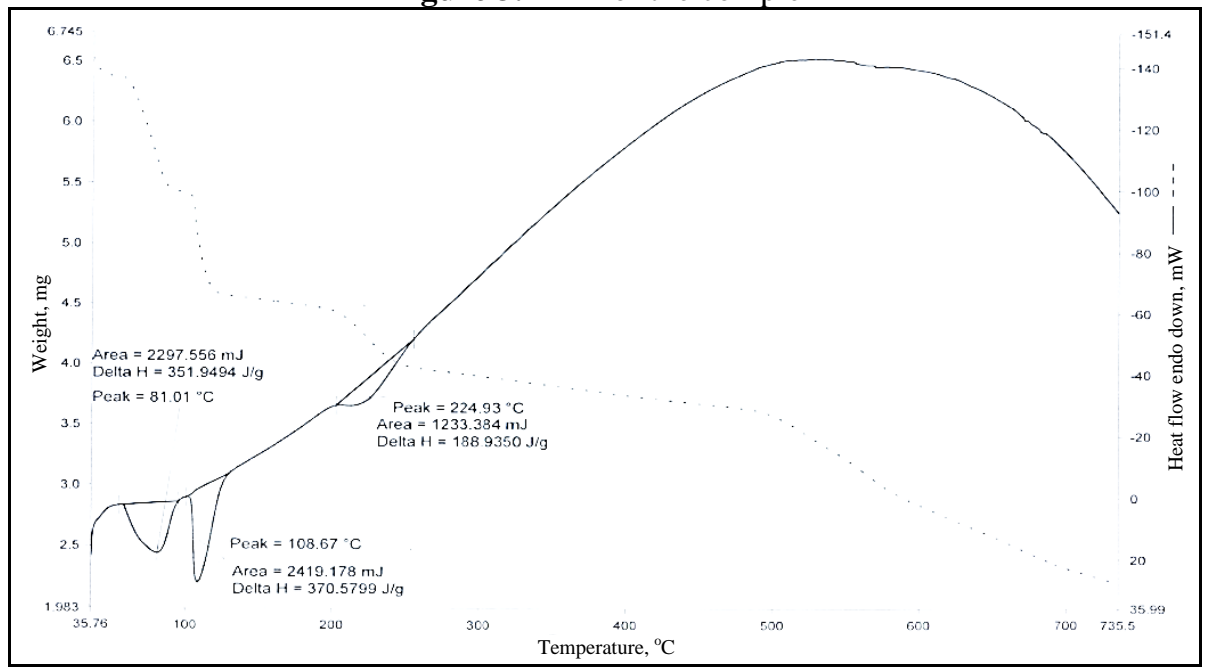

Figure 4. Enthalpy data of complex 
Elemental analysis viz. C, $\mathrm{H}, \mathrm{O}$ including $\mathrm{Cu}$ done through AAS shows that the percentage of carbon (40.17\%), hydrogen (6.30\%), oxygen (32.21\%) and copper $\left(2.3 \times 10^{5}\right.$ ppm i.e. $21.31 \%$ ) were corresponding to the theoretical values of the percentage of these available in the complex (Table 1). Hence $\mathrm{C}, \mathrm{H}, \mathrm{O}$ and $\mathrm{Cu}$ percentage data is in agreement with the proposed structure.

Table 1. Percentage of elements in the eugenol-copper complex

\begin{tabular}{cc}
\hline Element & $\% / \mathrm{ppm}$ present \\
\hline Carbon & $40.17(40.247)^{*}$ \\
Hydrogen & $6.30(6.37)^{*}$ \\
Oxygen & $32.21(32.193)^{*}$ \\
Copper & $2.3 \times 10^{5} \mathrm{ppm}=21.31 \%$ \\
& $\left(2.1 \times 10^{5} \mathrm{ppm}=21.19 \%\right)^{*}$ \\
\hline
\end{tabular}

*represents theoretical values

\section{Composition of complex}

Through Job's method, the composition of eugenol and copper in complex, was found to be1:1. Based on the above discussion following is the proposed structure:

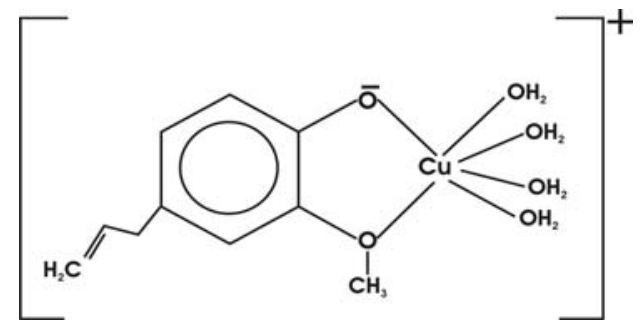

Figure 5. Structure of eugenol-copper complex

\section{Fungitoxic activity of complex}

According to Muruganandam et al. ${ }^{19}$, lipophilic activity of complex increases that extends the residential period on the susceptible host. As result of which the protection period on the host surface increases due to delayed decomposition of complex chelate and in turn efficiency of active ingredient increases. It is known that the existence of metal ions bonded to biologically active compounds may enhance their activities. Singh and Dhakarey ${ }^{20}$ also reported that metal complexes with Schiff bases derived from 2-thienyl glyoxal exhibited increased fungitoxic activity than the free ligands.

Eugenol-copper complex exhibited complete inhibition $(2 \% \pm 1.52)$ of conidial germination at $1 \mathrm{ppm}$ concentration and significant reduction of germination at $0.1 \mathrm{ppm}$ compared to eugenol $(98 \% \pm 1.52)$, $\mathrm{CuSO}_{4} \cdot 5 \mathrm{H}_{2} \mathrm{O}(98 \% \pm 1.52)$ at same concentration in $P$. grisea. In case of $H$. oryzae and C. lunata, complex exhibited significant reduction ( $85 \% \pm 2.31$ in $H$. oryzae, $82 \% \pm 1.16$ in C. lunata) of conidial germination compared to control $(98 \% \pm 2.31,1.16)$ at $10 \mathrm{ppm}$ concentration. Thus the complex was found to be more effective against $P$. grisea compared to latter two pathogens (Table 2). Varying degree of fungitoxic patterns viz. granulated cytoplasm, septal dissolution, granulated, thin and longer germ tube compared to that in control were observed at different concentrations. 
Table 2.Fungitoxicity of complex against conidial germination of phytopathogenic fungi of rice crop

\begin{tabular}{|c|c|c|c|c|c|c|c|c|c|}
\hline \multirow{3}{*}{ 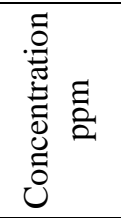 } & \multicolumn{9}{|c|}{ Pathogen } \\
\hline & \multicolumn{3}{|c|}{ P. grisea } & \multicolumn{3}{|c|}{ H. oryzae } & \multicolumn{3}{|c|}{ C. lunata } \\
\hline & Complex & Eugenol & $\mathrm{CuSO}_{4} \cdot 5 \mathrm{H}_{2} \mathrm{O}$ & Complex & Eugenol & $\begin{array}{c}\mathrm{CuSO}_{4} \cdot \\
5 \mathrm{H}_{2} \mathrm{O}\end{array}$ & Complex & Eugenol & $\begin{array}{c}\mathrm{CuSO}_{4} \cdot \\
5 \mathrm{H}_{2} \mathrm{O}\end{array}$ \\
\hline 100 & $2^{1}(8.13)$ & $45^{1,2,6}(42.13)$ & $10^{1,7,10}(18.44)$ & $15^{1}(22.75)$ & $89^{1,7}(70.63)$ & $85^{7}(67.21)$ & $4^{1}(11.54)$ & $50^{5}(45.00)$ & $80^{7}(63.44)$ \\
\hline 10 & $2^{1}(8.13)$ & $95^{1,7}(77.08)$ & $80^{1,7}(63.44)$ & $85^{3}(67.21)$ & $98^{10}(81.87)$ & $95^{3}(77.08)$ & $82^{3}(64.90)$ & 98 (81.87) & $90^{3}(71.56)$ \\
\hline 1 & $2^{1}(8.13)$ & 98 (81.87) & $90^{10}(71.56)$ & $98^{7,10}(81.87)$ & 98 (81.87) & $98^{3,7}(81.87)$ & $98^{7,10}(81.87)$ & 98 (81.87) & $98^{7,10}(81.87)$ \\
\hline 0.1 & $50^{1,7}(45.00)$ & 98 (81.87) & 98 (81.87) & $98^{10}(81.87)$ & 98 (81.87) & 98 (81.87) & $98^{10}(81.87)$ & 98 (81.87) & 98 (81.87) \\
\hline 0.01 & 98 (81.83) & 98 (81.87) & 98 (81.87) & 98 (81.87) & 98 (81.87) & 98 (81.87) & 98 (81.87) & 98 (81.87) & 98 (81.87) \\
\hline Control & 98 (81.83) & 98 (81.87) & 98 (81.87) & 98 (81.87) & 98 (81.87) & 98 (81.87) & 98 (81.87) & $98(81.87)$ & 98 (81.87) \\
\hline
\end{tabular}

C.D at $\mathrm{P}=0.05 .1 .52$ for $P$. grisea, 2.31 for $H$. oryzae, 1.16 for $C$. lunata. Data in parentheses represents angular values.

Complete inhibition of conidial germination is represented by $2 \%$. ${ }^{1}$ granulated conidial cytoplasm, ${ }^{3}$ excessive branched germ tube,

${ }^{5}$ thick germ tube, ${ }^{7}$ granulated germ tube, ${ }^{10}$ thin germ tube. 


\section{Conclusion}

New eugenol-copper complex was synthesized and characterized through FT-IR, TG/DTA, Elemental, AAS and Job's method. The FT-IR spectrum reveals the presence of $\mathrm{Cu}-\mathrm{O}$ bond at $603 \mathrm{~cm}^{-1}, 517 \mathrm{~cm}^{-1}$ and $585 \mathrm{~cm}^{-1}$.TG/ DTA corresponds to loss of four water molecule, allylic group and methoxy group. Elemental analysis and AAS done for $\mathrm{Cu}$ indicated the percentage of $\mathrm{C}, \mathrm{H}, \mathrm{O}$ and $\mathrm{Cu}$ corresponding to those of the calculated values. The composition of eugenol and copper in the complex was found to be 1:1. All these data were in conformity with the proposed structure of the complex. Fungitoxic activity of the complex was found to be enhanced compared to both eugenol and $\mathrm{CuSO}_{4} \cdot 5 \mathrm{H}_{2} \mathrm{O}$ tested alone especially against $P$. grisea, the causal agent of blast, which is globally, one of the most destructive diseases of rice crop. The other two pathogens, $H$. oryzae and C.lunata were also successfully inhibited by the complex compared to eugenol alone.

\section{Acknowledgement}

Authors thank Dr. T. Mohapatra, Director, Central Rice Research Institute, Cuttack and Dr. Anand Prakash, HoD, Crop Protection Division, CRRI. Authors are extremely thankful to Prof. (Dr) Ajay Patnaik (Former Professor, Chemistry Deparment, Khallikese college, Berhampur,Odisha, Prof. (Dr.) Prakash Mohanty (Former HoD, Chemistry Department, Utkal University, Odisha) and Dr. (Mrs.) Smrutiprava Das (HoD, Ravenshaw University) for their invaluable and indispensable support during the course of experiment and manuscript writing. Thanks are also due to Dr A.V. Suriyarao, Former Principal Scientist, CRRI for statistical analysis of the data. Senior author thanks Shri Arjuni Moharana, Techical Asst., Crop Protection Division for his support during the course of work. FT-IR, TG/DTA and Elemental analysis done by SAIF, Panjab University, Chandigarh, Panjab and STIC, Cochin University of Science and Technology, Cochin, Kerala are duly acknowledged.

\section{References}

1. Deans S, Noble R C, Hiltunen R, Wuryani W and Pe'nzesL G, Flavour Fragrance J., 1995, 10, 323-328.

2. Pandey R R, DubeyR C and Saini S, Afr J Biotechnol., 2010, 9(28), 4364-4368; DOI:10.5897/AJB10.147

3. Carrasco A H, Espinoza C L, Cardile V, Gallardoll C, Cardonal W, Lombardoll L, Catalan M K, Cuellar F V M and Russo A, J Braz Chem Soc., 2008, 19(3), São Paulo, http://dx.doi.org/10.1590/S0103-50532008000300024

4. $\quad$ Bartel H A, Am J Orthodont Oral Surg., 1947, 33, 458-465.

5. Bennis S, Chami F, Chami N, Bouchikhi T and Remmal A, Lett Appl Microbiol., 2004, 38(6), 454-458; DOI:10.1111/j.1472-765X.2004.01511.x

6. $\quad$ Devi K, Sakthivel R, Nisha S, Suganthy N and Pandian S, Arch Pharm Res., 2013, 36(3), 282-292; DOI:10.1007/s12272-013-0028-3

7. Mann R S and Kaufmann P E, Mini-Rev Org Chem., 2012, 9, 185-201; DOI:10.2174/157019312800604733.

8. $\quad$ Chatterjee A, Sukul N C, Laskar S and Ghoshmajumdar S, J Nematol., 1982, 14(1), 118-129.

9. Irie Y, Itokazu N, Anjiki N, Ishige A, Watanabe K and Keung W, Brain Res., 2004, 1011(2), 243-246; DOI:10.1016/j.brainres.2004.03.040

10. Moleyar V and Narasimham P, Int J Food Microbial., 1992, 16(4), 337-342; DOI:10.1016/0168-1605(92)90035-2 
11. Sangwan N K, Vermin B S, Verma K K and Dhindasa K S, Pestic Sci., 1990, 28(3), 331-335; DOI:10.1002/ps.2780280311

12. http://www.moh.hnet.be.ca/guildfood/Pdd/063/0006397.pdf

13. Awasthi P K, Dixit S C, Dixit N and Sinha A K, J Pharm Res., 2008, 1(2), 215-220.

14. Stitcht F D and Smith R M, J Dent Res., 1971, 50(6), 1531-1535; DOI:10.1177/00220345710500062801

15. Mitchell D F, J Dent Child.,1961, 28, 150-153.

16. Nene Y L and Thapliyal P L, Disease Fungicides in Plant Control, Oxford and IBH Publishing Co., New Delhi, Mumbai, Kolkata, 1979, 406-425.

17. Hasanvand F, Golyrostoni Z, Ghattali S M and Amani S, Arch Appl Sci Res., 2009, 1(2), 142-149.

18. Volanti D P, Orlandi M O, Andres J and Longo E, The Royal Society of Chemistry, Supplementary Material (ESI)-CrystEngComm, 2010, 3.

19. Muruganandam L, Kumar K K and Balasubramanian K, Chem Sci Trans., 2013, 2(2), 379-384; DOI:10.7598/cst2013.335

20. Singh P and Dhakarey R K S, Rasayan J Chem., 2009, 2(4), 869-874. 